\title{
Kūkaniloko: What It Means as the Piko of O'ahu
}

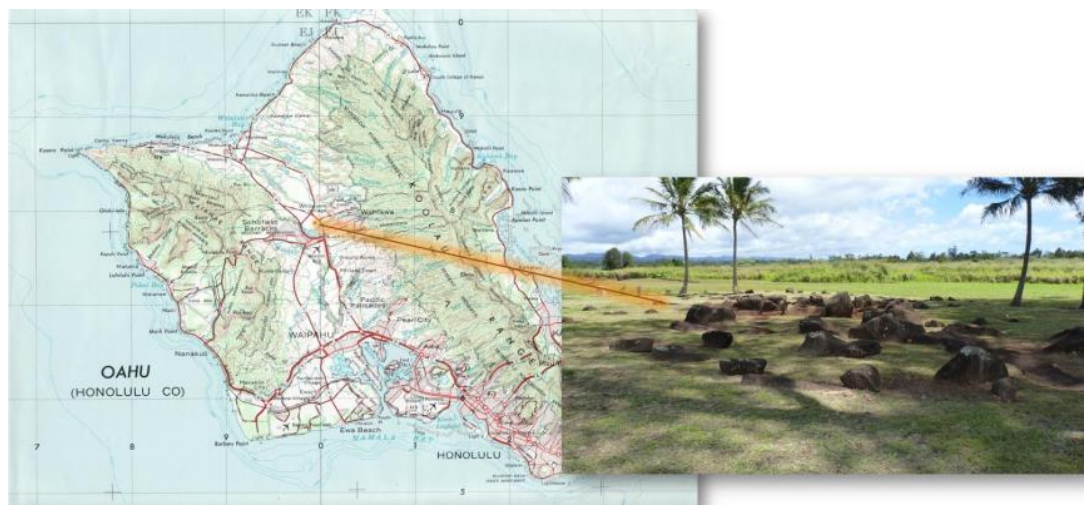

(From a talk on September 22, 2017 at the Kana'ina Building, 'Iolani Palace grounds, sponsored by Hui Aloha 'Āina o Honolulu)

Years ago an older man from Arizona well-versed in indigenous astronomies went with me to Kūkaniloko. He asked me, "there are seven directions - what are they?"

For about 12 years I've been researching precontact astronomy represented at Kūkaniloko, the site known as the piko of O'ahu - the navel, the center of the island. It is also one of only two royal birthing sites in Ka Pae 'Âina, the Hawaiian archipelago. The piko-ness of Kūkaniloko has been very much at the core of my research data. And that data showed that precontact astronomy at Kūkaniloko was about much more than sun stations, star rises and sets, calendrics, and navigation. The data showed that bigger ideas, things like the 
structure of space and time - wa and $k \bar{a}-$ and matters of gender relations, the importance of $a o$ and $p \bar{o}$, and other philosophical or metaphysical ideas were embedded in Kūkaniloko's astronomy.

The Pukui and Elbert dictionary's definition-translation of piko includes navel, umbilical cord, figuratively blood relative, genitals; the summit of a hill or mountain; crest; crown of the head; tip of the ear; end of a rope; border of a land; center, as of a konnane board; place where a stem is attached to a leaf; bottom round of a carrying net; thatch above a door.

So-What is a center? This list summarizes definitions from a variety of dictionaries:
A center is a midpoint.
It is an axis around which something revolves or rotates.
It is the source of an influence, an action, a force.
It is a place, person, or thing that is the most important
for an activity or condition.
It is the source from which something originates.
It is the core of a thing.
It is a point of mediation between opposites.

Thus the center mediates between/among things - between male and female, between stars, between sun and stars, between $a o$ and $p \bar{o}$, between earth and sky.

Kunkaniloko is at the center of the island of O'ahu. The center does not need balance: the center is the point at which balance occurs. But for the center to be a center there have to be at least two things to be at the center of. In the case of Kūkaniloko's astronomy that is both simple and complex. It is simple because the sun and every star has a rise in the east and a set in the west. It is complex because when more than one star or more than one sun station is included, relationships 
between/among the stars and the sun stations are created, and these relationships must also be referenced by the center.

The graphic below shows how the solstices and equinoxes are balanced - centered - at Kūkaniloko.

Figure 1. Solstices and Equinoxes Centered at Kūkaniloko

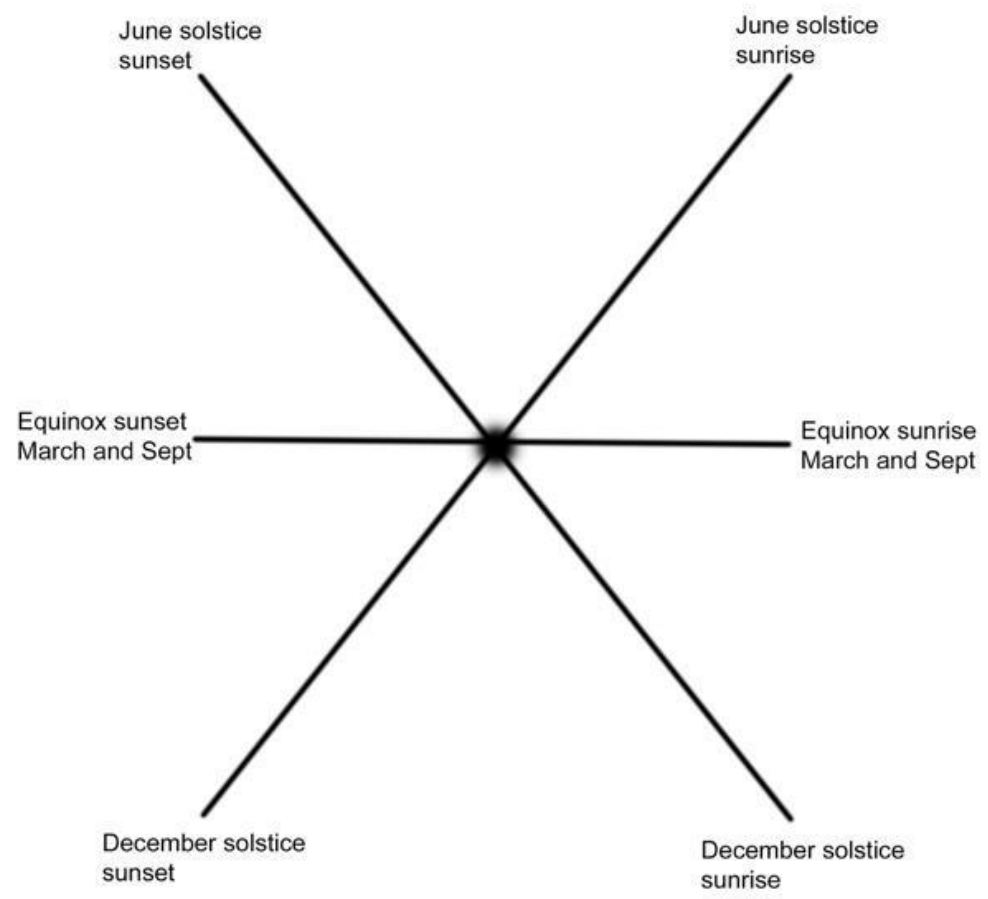

Solstice and Eqquinox sunrises ans sunsets centered at Kükaniloko 
The next graphic shows how star rises and sets are centered at Kūkaniloko.

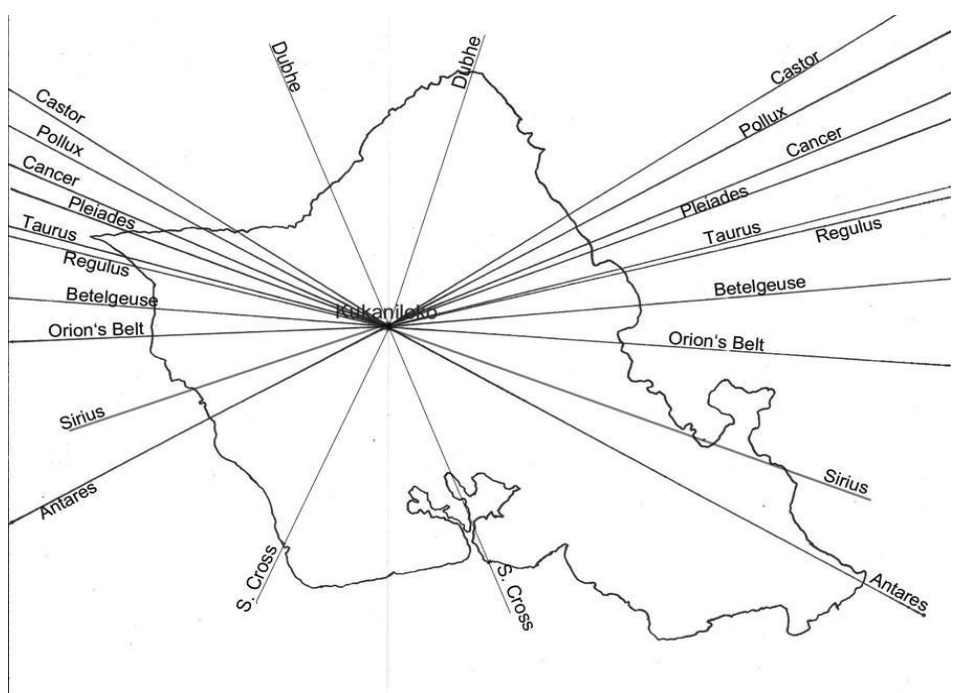

Figure 2. Centering Star Rises and Sets at Kūkaniloko

Any place can be understood as centered by star and sun rises and sets. What makes Kükaniloko unique is that the landscape markers for the sun and stars at sunrise and sunset are named for those celestial events as though they were visible from Kūkaniloko. In that way not only are the stars centered at Kükaniloko, but so, too, is the the geography of the island, and thus the island itself.

Why was it and is it that a particular place functions as a piko, as a navel and center? There are several reasons. One is the importance of a cultural and political nexus, a center of cultural and political importance from which information, such as periods for recognition of cultural importance, such as the birth of high-ranking infants or periods of certain observances is disseminated. Kükaniloko was a center for these things. But it was also a knowledge center, an educational center, and a spiritual center for O'ahu. These three things are really one 
thing - knowledge, education, and spirit are interdependent and interrelated.

A center is, of course, at the middle. A middle can be between two objects, or two moments in time, or two places.

\section{Wālua - Wā-lua}

two (lua) time/place (wā)

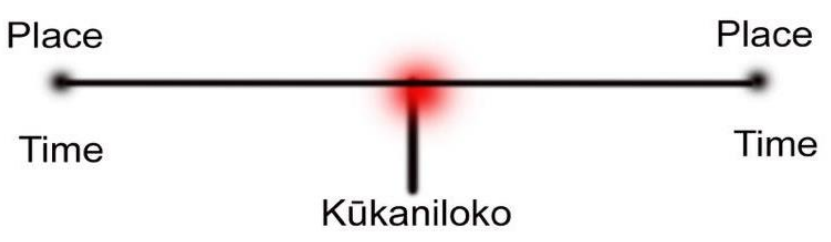

Figure 3. Wālua

The Pukui and Elbert dictionary gives wālua as the word for middle. Lua means two. Wā means time, space, and the interval between moments in time and/or places in space. The interval between times or places is not empty. It is a connecting interval - a kind of connecting tissue or ether or whatever one wants to call it. That is a metaphysical and spiritual understanding of the center.

A piko is a center, a maka (eye), an 'ōnohi (eyeball), $k a$ ' $i$ 'o (the heart of a matter, the essence of a thing or a place), the iho (axis), the ku'ina (the center that joins things).

As the piko of O'ahu, Kūkaniloko represents, well - pikoness. By "pikoness," I mean the inclusion of all the senses of piko - geographical, metaphysical, spiritual, biological, cosmogonic, astronomical, and personal. But of especial importance at Kükaniloko is the sun - who is and represents Kāne, the source of wisdom, knowledge, insight, and intuition.

The human body has three pikos. 


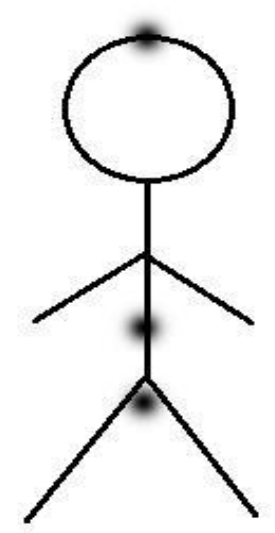

Figure 4. The body's three pikos

The Pukui and Elbert dictionary's definitions of piko include the umbilicus, the genitals, and the crown of the head. The piko on the crown of the head is the part of us closest to the daytime sun, to Kāne - the part of us closest to the daytime sky and heavens. The piko between our legs, our ma'i, genitals, is the piko closest to Papa, Mother Earth, and the sky below the earth. The piko we have in the middle, our umbilicus, our belly button, is the center that connects the piko above to the piko below. The three pikos - the crown of the head, the belly button, and the genitals - form the vertical axis of our bodies.

We can think of ourselves, our bodies, as a post or pillar or axis that runs from the manawa at the top of the skull through the center at our belly button to the $m a ' i$, the genitals. And we can consider the meaning of - and effect on - our body when it is at the piko, the geographical, cultural, and spiritual center of O'ahu that is Kūkaniloko.

A particularly potent time is when the sun is at the zenith and its rays can enter one's manawa- the center of the crown 
of the head, the juncture of the skull plates called the fontanel in infants - and through the head into the body to its central piko, the umbilicus, and from there to the third piko, the genitals.

Figure 5. The Tropics

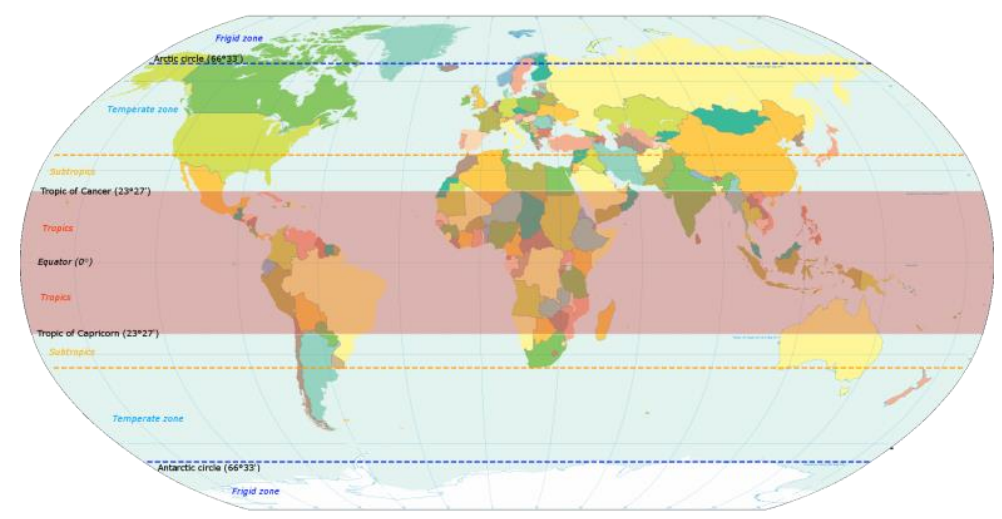

By KVDP - Own work, CC BY-SA 3.0,

https://commons.wikimedia.org/w/index.php?curid=2738507 $\underline{7}$

The solar zenith happens twice a year in the Tropics, and it only happens in the Tropics, the region between the Tropic of Cancer, at $23.5^{\circ}$ north of the equator, where the sun is at the June solstice, and the Tropic of Capricorn, at $23.5^{\circ}$ south of the equator, where the sun is at the December solstice. At the latitude of O'ahu the zeniths and take place about three weeks before and after the the June solstice and the nadirs take place about three weeks before and after the December solstice.

The solar zenith, like just about everything else in Hawaiian cultural astronomy, has a partner. The May zenith's partner is the November solar nadir, and the July zenith's partner is the January nadir, with the November nadir six months before the May zenith and the January nadir six months before the July zenith. 

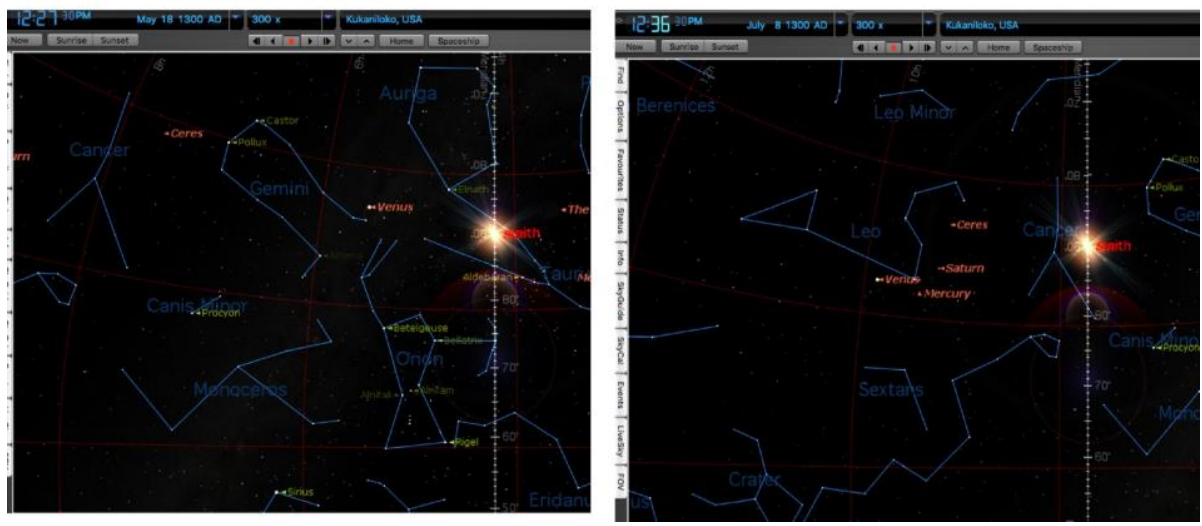

Figure 6. Left, Aldebaran and the sun at the May Zenith; Right, Cancer and the sun at the July zenith

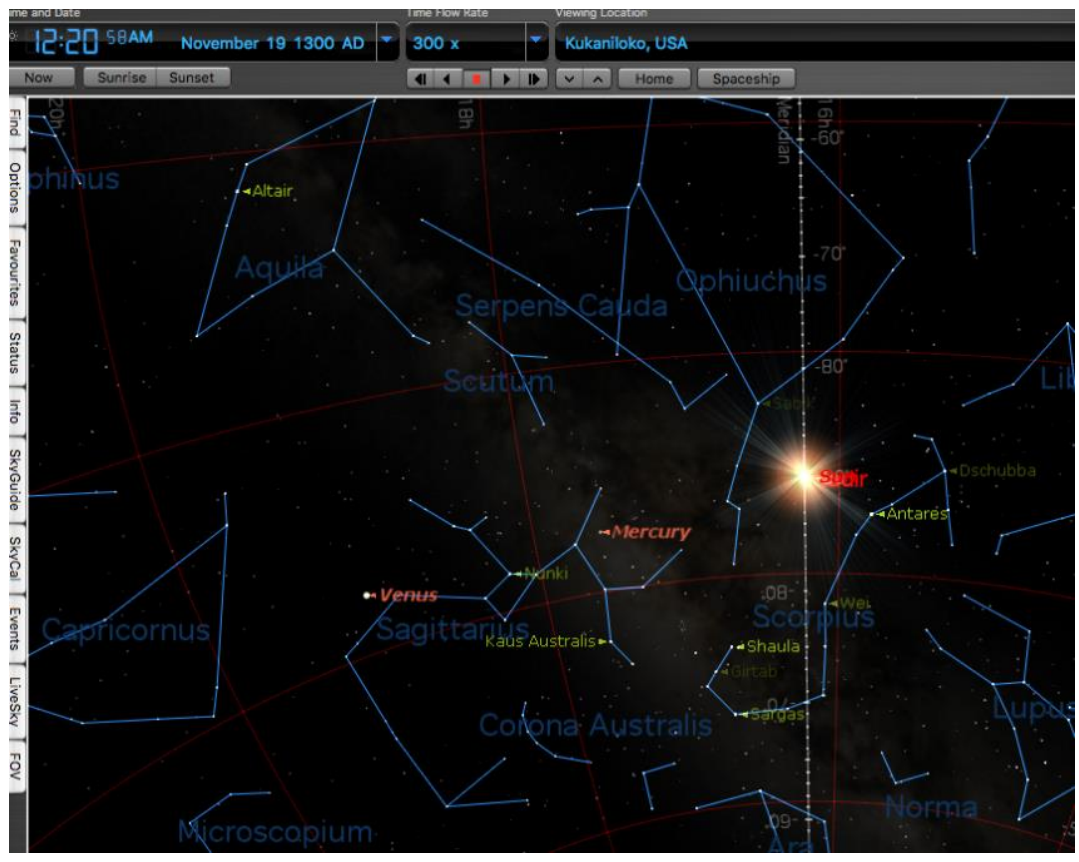

Figure 7. November solar nadir 


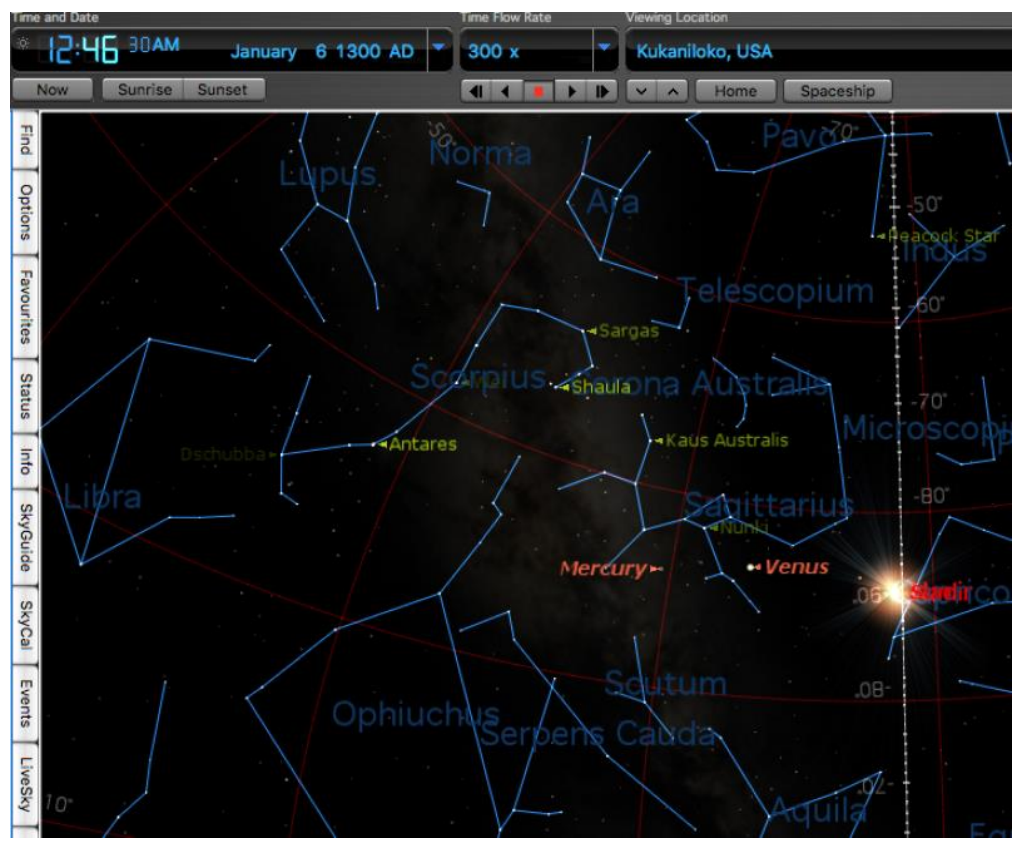

Figure 8. January solar nadir.

The nadir is the opposite of the zenith, the complement that creates unity. The zenith takes place when the sun is $90^{\circ}$ overhead. The nadir takes place when the sun is $90^{\circ}$ below your feet. The May zenith and November are more than partners and complements. They center the sky.

At the zenith the male (east) half of the sky and the female (west) half of the sky are united and equal in the sky above the earth. At the nadir the male (east) half of the sky and the female (west) half of the sky are united and equal in the sky below the earth.

When the May zenith takes place the sun is with Aldebaran, the bright red star in the constellation Taurus. When the May zenith's partner and complement, the November nadir, the sun is accompanied by Antares, the bright red star in the constellation Scorpius. 


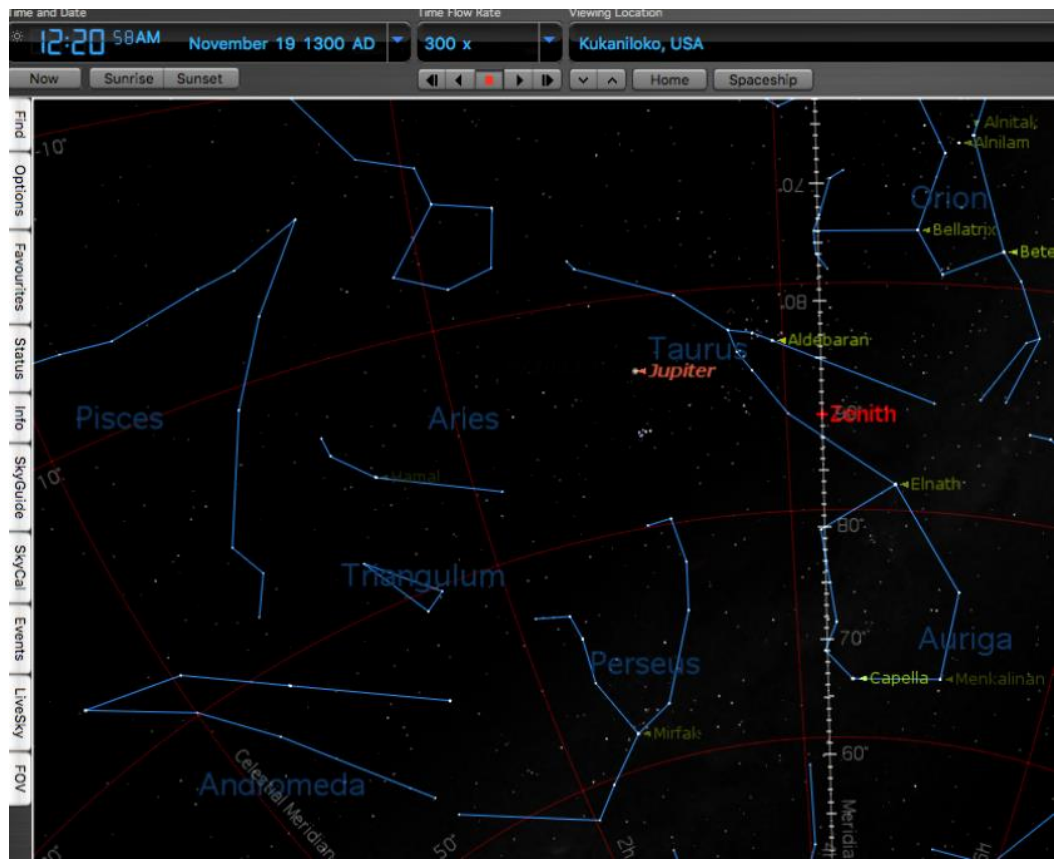

Figure 9. Aldebaran at the zenith at the time of the November solar nadir.

Aldebaran is female. She has among her names the name Haumea. Haumea is also Papa (mother earth), and sometimes also La'ila'i, and sometimes also Hina. As Papa she is a halfsister and mate of Wākea (sky father). Antares is male, a brother of Wākea. They have blood relationships, and they have roles in cosmogony/creation. They are, of course, opposites and complements because Aldebaran is female and Antares is male, but they have a special oppositeness and complementarity. They are literally opposite one another, $180^{\circ}$ apart in the sky.

At the November solar nadir, Antares is with the sun $90^{\circ}$ below and Aldebaran is at the celestial zenith $90^{\circ}$ above. In that way they are united. And in the unity of opposites complements - something productive takes place, something is 
created. That is an essential nature of complementarity, an essential outcome of the unity of opposites.

$$
90^{\circ} \text { above }
$$

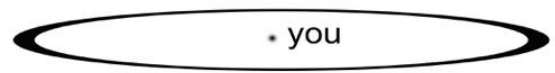

$$
90^{\circ} \text { below }
$$

Figure 10. Zenith and Nadir

One of the things created by this particular unity is the third axis. Just as our bodies have a piko above at the top of the head, a piko at the center at our belly button, and a piko below at our genitals, forming an axis through the midline of our bodies connecting our uppermost piko through the umbilicus to our lowermost piko, Kükaniloko has a third axis that unites the above through the middle to the below.

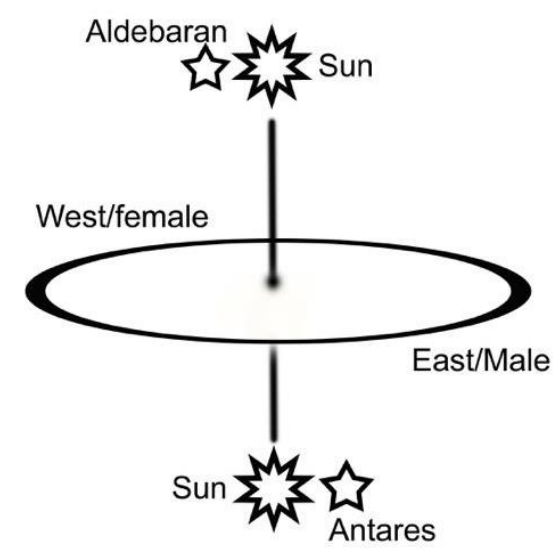

Figure 11. Zenith-nadir unification of male (east) and west (female) halves of the sky 
The two generally known axes are the east-west axis (here you can think of the equator and of the equinoxes) and the northsouth axis (approximated by Polaris and the Southern Cross). To these two axes other axes can be added, including the solstitial axes and the equinox axis and the nadir-zenith axis. These are all two-dimensional axes. And they all meet at Kükaniloko. The Aldebaran-Antares axis pierces the intersection (Kūkaniloko) of the axes. The Aldebaran-Antares axis adds the third dimension - up-down/above-below. The piko is the connection among them.

We are now in a holistic universe, in a holistic world, a world that is represented, symbolized, and recreated in our own bodies. Our bodies hold that knowledge. Even when we do not think about it or even know about it, our bodies hold that knowledge. And when our bodies are at Kūkaniloko, the place that is the piko of the island - the center of the island - our bodies - even when we do not know it or feel it or understand it - are related to and associated with, and in a symbolic and a personal way replicate, the island's piko. That is a big enough idea, but it is also a part of a wider idea or set of interlinked ideas.

O'ahu has two mountain ranges, the Ko'olau Range in the east and the Wai'anae Range in the west. Both ranges are close to their respective shorelines, and both have a spine or ridgeline that runs roughly north-south. The two mountain ranges provide landscape markers for the rise of stars in the east and the set of stars in the west. That would not be unusual, of course. But what is unusual is that the stars' landscape markers include places to the east of the Ko'olau Range and places to the west of the Wai'anae Range, thus places that could not have been and cannot be observed from Kükaniloko. 


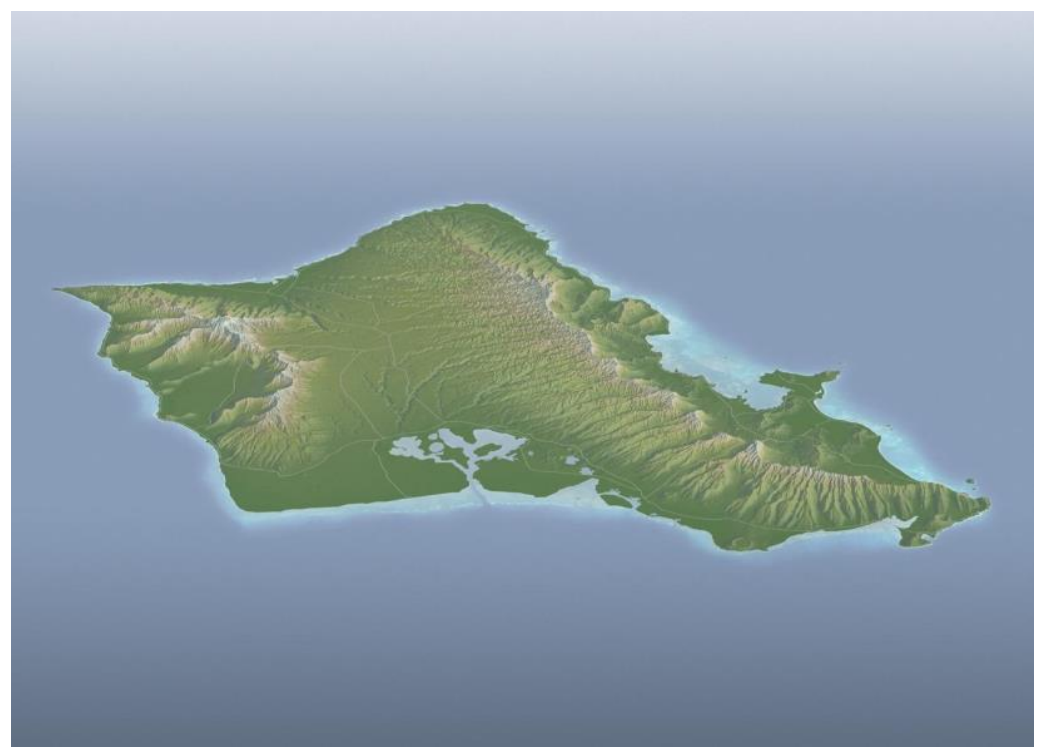

Figure 12. The Wai'anae Range (West) and the Ko'olau Range (East). From the National Park Service

That means that precontact sky experts were so knowledgeable about the cycles of stars that they were able to name places for the rise or set of stars they could not see. That is a big deal in the world of scholarly research about cultures“ astronomies. Most research has taken as a given that people in cultures that did not have a written language had to be able to visually observe a star rise or set. But Kūkaniloko's sky experts could "see," that is they knew where the rises and sets they couldn't observe took place. In the words of one of my grad school instructors, "You mean they knew celestial mechanics?!" Yes, they knew celestial mechanics.

We can see that from the names of stars' landscape markers. The landscape markers indicate the rise and set of stars from the point of view of Kūkaniloko. Naming places in this way, from the point of view of Kūkaniloko, is another way the island was centered at Kūkaniloko. 
The table below shows the rise and set azimuth of a few stars and the corresponding compass bearing for each star's landscape markers.

Table 1. Hinaiaeleele/Aldebaran, Antares, Gemini, Pleiades and landscape markers

\begin{tabular}{|c|c|c|c|c|c|c|c|}
\hline $\begin{array}{l}\text { Star and } \\
\text { sun } \\
\text { stations }\end{array}$ & $\begin{array}{l}\text { Rise/Set } \\
\text { dates }\end{array}$ & $\begin{array}{l}\text { Rise } \\
\text { azim } \\
\text { uth }\end{array}$ & $\begin{array}{l}\text { Rise marker } \\
\text { bearing }\end{array}$ & $\begin{array}{l}\text { Set } \\
\text { azimuth }\end{array}$ & $\begin{array}{l}\text { Set } \\
\text { marker } \\
\text { bearing }\end{array}$ & $\begin{array}{l}\text { Sunset } \\
\text { azimuth }\end{array}$ & $\begin{array}{l}\text { Sunset } \\
\text { marker at } \\
\text { star evening } \\
\text { rise }\end{array}$ \\
\hline $\begin{array}{l}\text { Aldebaran } \\
\text { May zenith } \\
\text { - May } 13 \\
\text { Nov nadir - } \\
\text { Nov } 20\end{array}$ & $\begin{array}{lr}77 & \\
& \\
\text { AM } & \mathrm{R} \\
\text { May } & 23 \\
\text { AM } & \mathrm{S} \\
\text { Nov.8 } & \\
\text { PM } & \mathrm{R} \\
\text { Nov } 21 & \\
\text { PM } & \mathrm{S} \\
\text { May } 5 & \end{array}$ & 77 & $\begin{array}{l}81-85 \\
\text { Kanehoalani } \\
79 \text { Pauao - } \\
\text { mediator } \\
74-80 \\
\text { Kaaawa - } \\
\text { premature } \\
\text { infant } \\
72 \text { Kahana - } \\
\text { ridgepost; } \\
\text { work }\end{array}$ & 284 & $\begin{array}{l}293 \\
\text { Kamana } \\
\text { nui } \\
\text { great } \\
\text { mana }\end{array}$ & 244 & $\begin{array}{l}244 \quad \text { Puu } \\
\text { Kailio - Dog } \\
\text { Mountain }\end{array}$ \\
\hline $\begin{array}{l}\text { Hinaieleele } \\
\text {-Aldebaran } \\
\text { with } \quad 3 \\
\text { other } \\
\text { Hyades } \\
\text { stars }\end{array}$ & \begin{tabular}{lr} 
AM & \multicolumn{1}{r}{} \\
May & 24 \\
AM & S \\
Nov 6 & \\
PM & $R$ \\
Nov & 21 \\
PM & S \\
May & 5
\end{tabular} & $\begin{array}{l}74- \\
76\end{array}$ & $\begin{array}{l}81-85 \\
\text { Kanehoalani } \\
79 \text { Pauao - } \\
\text { mediator } \\
74-80 \\
\text { Kaaawa - } \\
\text { premature } \\
\text { infant } \\
72 \text { Kahana - } \\
\text { ridgepost; } \\
\text { work }\end{array}$ & $284-286$ & $\begin{array}{l}293 \\
\text { Kamana } \\
\text { nui } \quad- \\
\text { great } \\
\text { mana }\end{array}$ & 244 & $\begin{array}{l}244 \quad \text { Puu } \\
\text { Kailio - Dog } \\
\text { Mountain }\end{array}$ \\
\hline $\begin{array}{l}\text { Antares } \\
\text { Nov. nadir } \\
\text { (Nov. 21) }\end{array}$ & $\begin{array}{l}\text { AM R R } \\
\text { Nov } 20 \\
\text { AM } \quad S \\
\text { May } 4 \\
\text { PM R R } \\
\text { May } 18 \\
\text { PM S Nov } \\
2\end{array}$ & 119 & $\begin{array}{l}\text { 119 Halekou } \\
- \text { house of } \\
\text { male potency } \\
119 \\
\text { Kahanalii - } \\
\text { chief's place; } \\
\text { chief's work } \\
119 \\
\text { Kahiakahoe - } \\
\text { to work the } \\
\text { fireplow } \\
121 \\
\text { Konahuanui } \\
- \text { his big } \\
\text { testicles }\end{array}$ & 241 & $\begin{array}{l}241 \text { Puu } \\
\text { Hapapa- } \\
\text { hawk- } \\
\text { catching } \\
\text { hill; } \\
\text { breath } \\
\text { (life) of } \\
\text { Papa; } \\
\text { portion } \\
\text { of an } \\
\text { enclosur } \\
\text { e }\end{array}$ & 291 & $\begin{array}{l}289 \\
\text { Kaupakuhale } \\
-\quad \text { house } \\
\text { beam; } \\
\text { figuratively } \\
\text { the greatest }\end{array}$ \\
\hline
\end{tabular}




\begin{tabular}{|c|c|c|c|c|c|c|c|}
\hline $\begin{array}{l}\text { Gemini } \\
\text { June } \\
\text { solstice } \\
\text { (June 13) }\end{array}$ & \begin{tabular}{ll} 
AM & \multicolumn{1}{c}{ R } \\
June & 26 \\
AM & S \\
Dec & 15 \\
PM & \\
Dec & 23 \\
PM & \\
June & 13
\end{tabular} & $\begin{array}{l}58- \\
65\end{array}$ & $\begin{array}{l}57 \text { Kaluanui } \\
- \text { the great } \\
\text { two } \\
61 \text { Makaua - } \\
\text { we two }\end{array}$ & 299-304 & $\begin{array}{l}301 \\
\text { Aukuu } \\
292-293 \\
\text { Mahoe } \\
\text { Pali } \\
297 \\
\text { Kawaiha } \\
\text { pai } \\
293 \\
\text { Kamana } \\
\text { nui }\end{array}$ & 244 & $\begin{array}{l}244 \quad \text { Puu } \\
\text { Kailio - Dog } \\
\text { Mountain }\end{array}$ \\
\hline Pleiades & $\begin{array}{lr}\text { AM } & \text { R } \\
\text { May } & 7 \\
\text { AM S } & \text { Oct } \\
31 & \\
\text { PM } & R \\
\text { Nov } & \text { PM } \\
\text { S Apr } & 26\end{array}$ & 69 & $\begin{array}{l}65 \text { Makalii Pt } \\
\text {-Pleiades Pt }\end{array}$ & 291 & $\begin{array}{l}290 \text { Alei } \\
\text { - to leap; } \\
\text { beloved } \\
290 \text { Alau } \\
- \\
\text { dividing, } \\
\text { branches }\end{array}$ & 248 & $\begin{array}{l}252 \quad \text { Puu } \\
\text { Kumakalii - } \\
\text { Mountain } \\
\text { Pleiades Rise }\end{array}$ \\
\hline
\end{tabular}

Taking a closer look at a few of the stars and landscape markers shows how they help us understand the nature of piko-ness. 


\begin{tabular}{|c|c|c|c|c|c|c|}
\hline & East & Event & Star & West & Event & Star \\
\hline 1. & $\begin{array}{l}\text { Makalii } \\
\text { Point }\end{array}$ & $\begin{array}{l}\text { Season } \\
\text { change }\end{array}$ & Pleiades & Puu Kumakalii & $\begin{array}{l}\text { Season } \\
\text { change }\end{array}$ & $\begin{array}{l}\text { Pleiades } \\
\text { and sun }\end{array}$ \\
\hline \multicolumn{7}{|c|}{ Ala is road or path. A la is of the sun. } \\
\hline 2. & $\begin{array}{l}\text { Kane- } \\
\text { hoalani }\end{array}$ & Solstices & Betelgeuse & Kaneana & Solstices & Betelgeuse \\
\hline & Kaneilio & Nadirs & Sun, Sirius & Puu Kailio & Nadirs & Sun, Sirius \\
\hline \multicolumn{7}{|c|}{$\begin{array}{l}\text { Kane is the god Kāne, who is the Sun. 'Tllio is dog. Dog has several functions, among them being a } \\
\text { guide for the deceased, a guardian, and the liminal being at the portal and change from pō to ao in } \\
\text { cosmogony and from ao to pō in a human life }\end{array}$} \\
\hline 3. & Koiele & Solstices & Betelgeuse & Koiahi & Solstices & Betelgeuse \\
\hline \multicolumn{7}{|c|}{$K o^{\prime} i$ is solstice. } \\
\hline 4. & $\begin{array}{l}\text { Kaau- } \\
\text { makua }\end{array}$ & Equinoxes & Sun & Makua & Solstices & Betelgeuse \\
\hline \multicolumn{7}{|c|}{ Makua is parent, person(s) of previous generations, progenitor. Akua means god. } \\
\hline 5. & Kaaawa & $\begin{array}{l}\text { May } \\
\text { zenith, } \\
\text { Nov nadir }\end{array}$ & Aldebaran & Keawaula & $\begin{array}{l}\text { May } \\
\text { zenith, } \\
\text { Nov nadir }\end{array}$ & Aldebaran \\
\hline \multicolumn{7}{|c|}{$\begin{array}{l}\text { 'Awa is a premature infant, as was born from Wākea's incest with his and Papa's daughter. The } \\
\text { incest caused caused Wākea and Papa to separate, after which Papa took the name Haumea, one of } \\
\text { the names for Aldebaran. }\end{array}$} \\
\hline \multirow[t]{2}{*}{6.} & Kahana & $\begin{array}{l}\text { May } \\
\text { zenith, } \\
\text { Nov nadir, } \\
\text { Jul zenith }\end{array}$ & \multicolumn{2}{|l|}{$\begin{array}{l}\text { Aldebaran, } \\
\text { Cancer }\end{array}$} & $\begin{array}{l}\text { May } \\
\text { zenith, } \\
\text { Nov nadir }\end{array}$ & Aldebaran \\
\hline & Kahanalii & $\begin{array}{l}\text { Nov nadir, } \\
\text { Dec } \\
\text { solstice }\end{array}$ & \multicolumn{2}{|l|}{ Antares } & & \\
\hline \multicolumn{7}{|c|}{ Kahana is a turning point, a drawing of a line. Ka-Hānā is the $(k a)$ ridgepost ( $h \bar{a} n \bar{a})$. } \\
\hline \multirow[t]{2}{*}{7.} & Kamana & $\begin{array}{l}\text { Dec } \\
\text { solstice }\end{array}$ & Sun & Kamananui & $\begin{array}{l}\text { June } \\
\text { solstice }\end{array}$ & Sun \\
\hline & $\begin{array}{l}\text { Mana- } \\
\text { mana }\end{array}$ & Solstices & Betelgeuse & & & \\
\hline \multicolumn{7}{|c|}{ Mana is divine/supernatural power, empower, branch or crosspiece, rays of the sun. } \\
\hline 8. & Ulupo & Nadir & Sun, Sirius & Pokai & Nadir & Sun, Sirius \\
\hline \multicolumn{7}{|c|}{$\begin{array}{l}P \bar{o} \text { is night, realm of the gods, mystery, potentiality, the realm of ancestors and the dead, the } \\
\text { unknown, and the not yet born. }\end{array}$} \\
\hline 9. & Alala & Nadirs & Sun & Kaala & Equinoxes & Sun \\
\hline
\end{tabular}

\section{Table 2. Paired names}

One pair like these might be a coincidence. Nine is not a coincidence. Why did the sky and land experts do this? For one thing naming places on the opposite sides of the island with names that almost repeat one another magnifies the connection of the periphery of the island to the center. It also puts the two members of each pair in a relationship with one another whether it is two places for one star as with Aldebaran and the awa names and the kahana names, Betelgeuse with Kāne 
names, $p \bar{o}$ and 'ilio names for the sun and Sirius, the mana names for the solstices.

The three-place-name stars show a more complex relationship. One of these is the mana names, two of which are for the sun at the solstices and the third of which is for Betelgeuse whose morning rise and evening rise closely coincide with the solstices. The other is Kahana and Kahanahaiki for Aldebaran and Kahanalii for Antares. This is because Aldebaran and Antares are a special quality of pair - male and female high chiefs, whose union gives us the third axis, and whose work in the sky includes creating and ruling over celestial structure of space and time. ${ }^{1}$

Returning to the centeredness, the piko-ness, the mediating and uniting functions and effects of the center, we can look further at the Pukui and Elbert definitions:

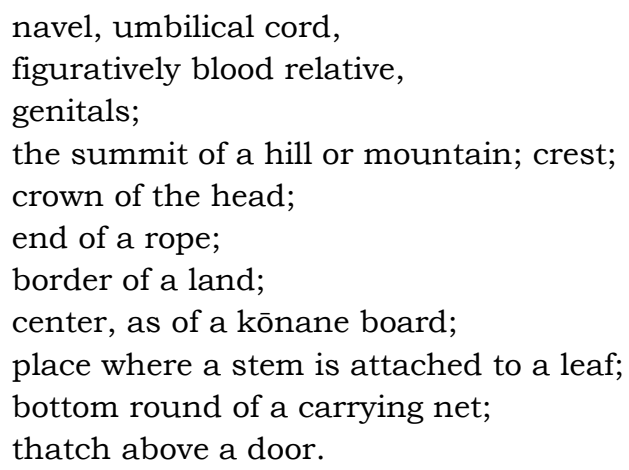

Navel, of course, is a reference to Kūkaniloko and together with umbilical cord is a reference to Kükaniloko as the royal birthing site. But it is also not only the island's navel and our individual physical navels, it is the umbilical cord that connects places and people to Papa - cosmogony and Mother Earth - and stars to places on the island.

Martha Noyes, "From Kūkaniloko: the Celestial Rulers of Space and Time," Te Kaharoa, Vol. 10, 2017. 
Blood relatives refers to genealogy, particularly to chiefly genealogies whose blood inheritance reaches back to the beginning - not just to Papa and Wākea in the era of $a o$, but also farther back into the eras of $p \bar{o}$, and possibly even farther back to Io in Kolekole.

Genitals is another piko reference, to the piko between our legs, that part of us that participates in the creation of a new child. And that child is a continuation of genealogy into the future. And we remember that our genital piko is itself a product of our ancestors whose reproduction and genealogy gave life to each of us.

The summit of a hill of mountain, or the crest, recognizes the above-below, up-down hierarchical organization of the process of creation and of the culture. At the summit, one is closer to the sun and stars, and the closer one is to the sun and stars, the greater one's awareness of that connection and its meanings is. Height matters, even for celestial objects. They are at their greatest power when they are at their zenith, the highest point in their passage across the sky.

The crown of the head, the uppermost piko of a person, the manawa, is the summit of our body.

The end of a rope is also a center. When you measure something, the rope, or in our modern world a tape measure, is secured at the beginning of the measurement - its piko. It is also a reference to the rope or road of the sun, the ecliptic. The ecliptic begins and ends at the solstices, the opposite ends of the year - with the equinoxes at the middle of the journey. 


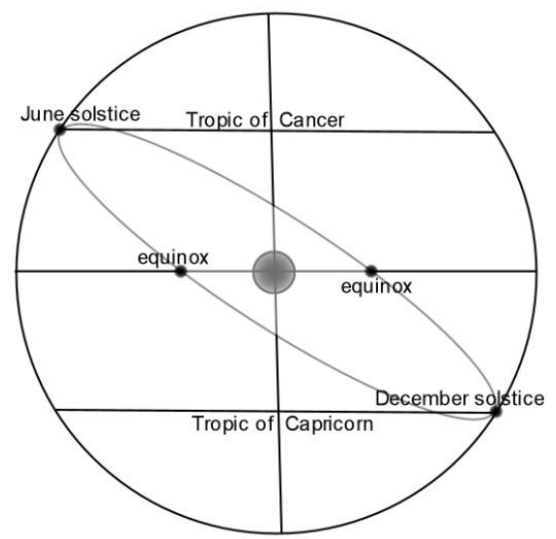

Figure 13. Celestial architecture

We can also see the rope as the imaginary line from Kūkaniloko to the rise and set of stars and sun, centering celestial motion at Kūkaniloko.

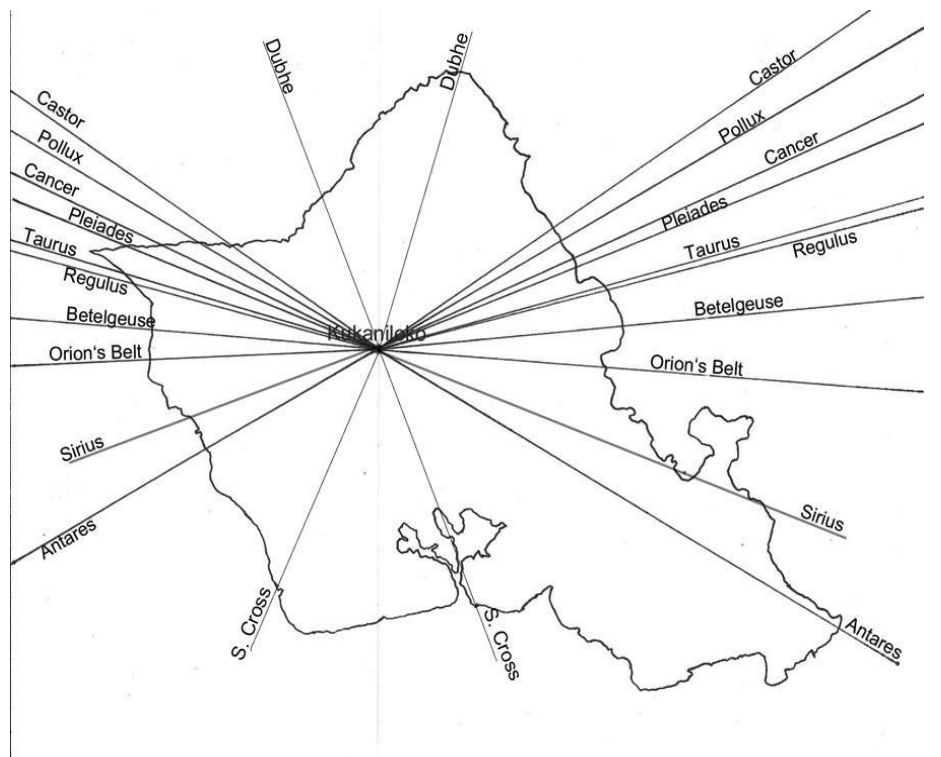

Figure 14. Stars centered at Kūkakniloko. 
Border of a land has multiple references. The borders of the island are the points of attachment of the periphery to the center. They are also how we orient ourselves on the land, thus how we find our center at the moment.

And this brings us back to the question the Arizona elder asked. What are the seven directions? They are above and below, left and right, in front and in back, and where you are (the center).

And how does that matter? It is a portable construct. It goes with you, it is wherever you are. And if your spiritual or cultural or knowledge center is Kūkaniloko, you carry that knowledge with you. It allows you to center yourself using stars, using Kükaniloko's understanding of the relationships of stars and the sun centered on a place - in other words that knowledge is with you and where you are is the center.

The borders of lands within the island - the mokus - are also markers for stars from the point of view of Kūkaniloko, again a centering of O'ahu at Kūkaniloko that unites each moku and all of the mokus at the center.

Konnane is the Hawaiian board game that resembles checkers. But konnane also means the bright light of the moon and to shine like the moon. This recalls the moon as Hina and Hina's association with Papa and Haumea and La'ila'i. This in turn recalls creation and the advent of humankind.

Nane of kōnane means riddle and to speak in parables. A riddle is a clever word game, but as Tui Atua Tupua Tamasese Ta'isi Efi phrased it, the riddle, the parable, is also the mystery of deity. ${ }^{2}$

The place where a stem is attached to a leaf refers again to genealogy, to the attachment of the periphery to the center, to the metaphors of family -including the families of gods and stars, to the dependence of the younger on the older and the connection of the present to the past.

2 Tui Atua Tupua Tamasese Ta'isi Efi, "Tupualegase: The Eternal Riddle," Official Speeches, http://www.head-of-statesamoa.ws/pages/speech_tupualegase.html 
The bottom of a carrying net refers to birth, old age, and death. The carrying net also suggests the 'eke, the basket made up of Aldebaran and three of the Hyades, and the container that is the womb.

The thatch above a door is the last part of building a hale, a house. The building of a house repeats the construction of the sky.

Ikuwa (Antares) and Haumea (Aldebaran) are the stars who rule the structure of space and time. The structure is perceived as a house, with posts, roofbeam, rafters, purlins, thatch, and so on - all of which figure in the names and landscape marker names of Antares and Aldebaran.

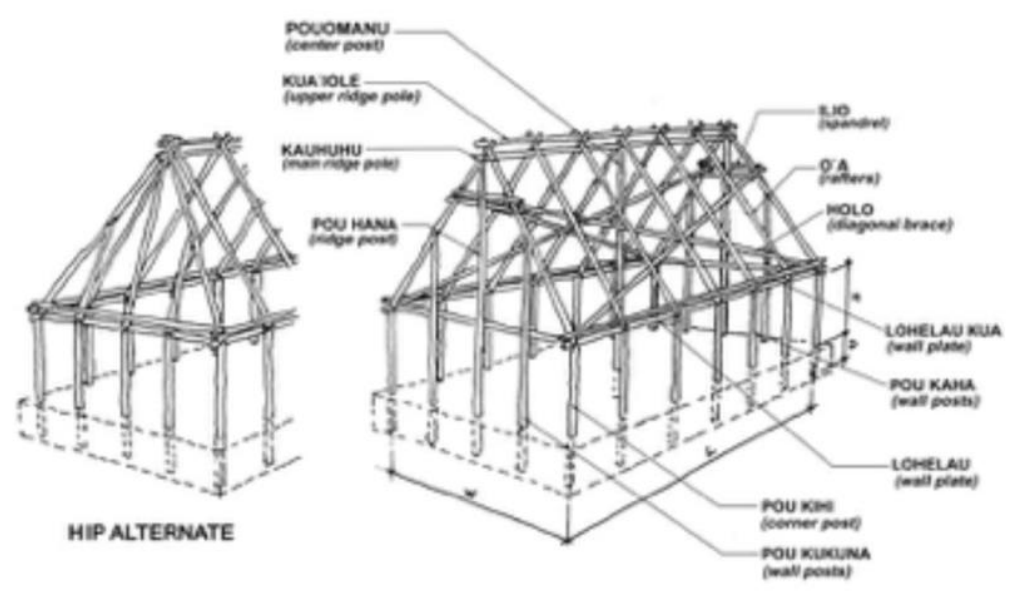

\section{hale halawai}

From Hawaii County, Public Works ${ }^{3}$

Figure 14. The structure of a hale halawai

3 Building Code, Department of Public Works, County of Hawaii, Appendix X, Section 402, at http://www.hawaiicounty.gov/pwnew-bldg-code/ 
Before a completed house could be entered the thatch over the door was trimmed and a kahuna prayed the Kuwa prayer. When the Kuwa prayer was done the house could be entered. In Chapter 33 of Hawaiian Antiquities, Malo provided a Kuwa prayer:

"Ku lalani ka pule a keoloalu i ke akua

O Kuwa wahi'a i ke piko o ka hale o Mea

A ku! A wa! A moku ka piko

A moku, a moku iho la!

Orderly and harmonious is the prayer of the multitude to God

Kuwa now cuts the piko of the house of Mea

He stands! He cuts! The thatch is cut.

It is cut! Lo it is cut!"4

In the second line Kuwa stands for Ikuwa (Antares) and Mea stands for Haumea (Aldebaran).

Here we look at the names for Aldebaran and Antares to see what their names tell us about some of the characteristics that relate them to the piko. These names for Aldebaran show her association with femaleness, conception and pregnancy, and with cosmogony. They also show her status as a high ali $i$ and a ruler.

Table 3. Names of Aldebaran

\begin{tabular}{|l|l|}
\hline Name & Celestial meaning/reference \\
\hline Haumea & $\begin{array}{l}\text { Goddess of childbirth; to organize (hang, } \\
\text { gird, lace, tie); at times also meaning Papa, } \\
\text { La'ila'i, and/or Hina }\end{array}$ \\
\hline Oma & High officer of a chief \\
\hline
\end{tabular}

4 David Malo, Hawaiian Antiquities, Honolulu: Honolulu Gazette Co., 1903, p. 164 at http://www.ahamoku.org/wpcontent/uploads/2011/12/Malo-David-Hawaiian_AntiquitiesMoolelo-Hawaii-translated-by-N-B-Emerson-Honolulu-HawaiianGazette-Co-Ltd-1903.pdf 


\begin{tabular}{|l|l|}
\hline & $\begin{array}{l}\text { 'Oma - oven; sacrificial victim; first man } \\
\text { killed in war; space where first man killed } \\
\text { in war was sacrificed; small adze }\end{array}$ \\
\hline Keoma & $\begin{array}{l}\text { The Oma and the 'Oma } \\
\text { Blasted, as fruit; jealous } \\
\text { Lilioma - to organize (hang, gird, lace, tie) }\end{array}$ \\
\hline Muakeoma & $\begin{array}{l}\text { The first or senior line and future } \\
\text { Oma/'Oma }\end{array}$ \\
\hline Hulikahikeoma & Oma/'Oma turns at this place (the zenith) \\
\hline Keoma-aiku & The ruling high officer of a chief \\
\hline Kapuahi & Fireplace, oven; sacred fire \\
\hline Unu & Altar, heiau; to draw together \\
\hline Hokuula & Red star \\
\hline
\end{tabular}

Her landscape markers reflect her names.

Table 4. Landscape markers for Aldebaran

\begin{tabular}{|c|c|c|c|c|c|c|c|}
\hline $\begin{array}{l}\text { Hinaiael } \\
\text { e-ele- } \\
\text { Aldebar } \\
\text { an } \\
\text { May } \\
\text { zenith } \\
\text { (May } 13 \text {, } \\
\text { - } 4.4^{\circ} \\
\text { alt) } \\
\text { Nov } \\
\text { nadir } \\
\text { (Nov } 20 \text {, } \\
6.6^{\circ} \text { alt., } \\
\text { zenith at } \\
\text { midnigh } \\
\text { t) }\end{array}$ & $\begin{array}{l}\text { AM } \\
\text { r } \\
\text { Ma } \\
\text { y } \\
24, \\
\text { s } \\
\text { No } \\
\text { v } 6 \\
\text { PM } \\
\text { r } \\
\text { No } \\
\text { v } \\
21, \\
\text { s } \\
\text { Ma } \\
\text { y } 5\end{array}$ & $\begin{array}{l}74 \\
- \\
76\end{array}$ & $\begin{array}{l}81-85 \\
\text { Kanehoala } \\
\text { ni - Kāne } \\
\text { who rules } \\
\text { the } \\
\text { heavens } \\
79 \text { Pauao- } \\
\text { mediator } \\
74-80 \\
\text { Kaaawa - } \\
\text { premature } \\
\text { infant } \\
72 \\
\text { Kahana - } \\
\text { ridgepost; } \\
\text { work }\end{array}$ & $\begin{array}{l}284 \\
- \\
286\end{array}$ & 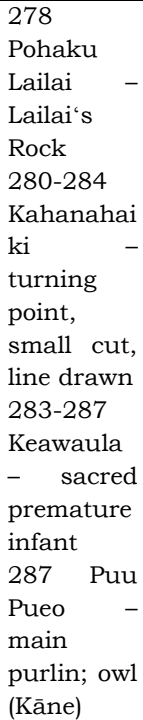 & $\begin{array}{l}29 \\
3 \\
24 \\
4\end{array}$ & $\begin{array}{l}293 \\
\text { Kamanan } \\
\text { ui - } \\
\text { great } \\
\text { mana } \\
244 \text { Puu } \\
\text { Kailio - } \\
\text { dog mtn. }\end{array}$ \\
\hline
\end{tabular}

Kaneholani tells us she is related to Kāne. All stars are related to Kāne, but Aldebaran has a particular set of 
relationships to him. Kāne and Wākea have a symmetrical relationship - that means that in some respects they are equivalent. As Papa, Aldebaran was the mate of Wākea. And again as Haumea she was the mate of Wākea. In some Polynesian cosmogonies she and Wākea are the parents of Kāne. In those cosmogonies it is Kāne who separated Papa from Wākea.

Her relationship to Kāne is also evident at the May zenith when she and the sun are together when the sun is at its highest place in the sky. That relationship is also present at the November solar nadir, when she is at the celestial zenith when Antares and the sun are together below the earth - the moment when the third axis is apparent to the sky experts.

Pōhaku La'ila'i recalls the symmetry or equivalence among Papa, Haumea, Hina, and La'ila'i, and the cosmogony and mo'olelo about them. Kaaawa and Keawaula refer to the first Hāloa who was premature and stillborn, from whose burial place the first kalo (taro) plant emerged. This is again cosmogony.

Kahana and Kahanahaiki refer to structure and show eastwest unity through Kūkaniloko.

Below are tables for the names of Antares and for the landscape markers for Antares:

Table 5. Names of Antares

\begin{tabular}{|l|l|}
\hline Name & Celestial meaning/reference \\
\hline Lehua & $\begin{array}{l}\text { Blossom of 'ōhīa; warrior; first man killed in } \\
\text { battle }\end{array}$ \\
\hline Polehua & Antares in pō \\
\hline Lehuaula & Red lehua \\
\hline Lehua-kona & Southern lehua \\
\hline Ikuwa & Great ruler of space and time \\
\hline Kukulukulu & $\begin{array}{l}\text { Pillar, post, to build a house; to construct, } \\
\text { organize; to lay an oven; timber used in } \\
\text { houses }\end{array}$ \\
\hline Nakulu & Timber used in houses \\
\hline
\end{tabular}




\begin{tabular}{|l|l|}
\hline Mehakuakoko & $\begin{array}{l}\text { Solitary master/lord [who] arranges, puts in } \\
\text { order, ties up strings/rope, and fulfils }\end{array}$ \\
\hline Kahuaokalani & $\begin{array}{l}\text { The foundation of heaven/sky; the regent of } \\
\text { heaven realm; the caretaker/regent of royal } \\
\text { enlightenment }\end{array}$ \\
\hline Hua & $\begin{array}{l}\text { Seed, testicles - maybe short for } \\
\text { Kahuaokalani }\end{array}$ \\
\hline Hai & $\begin{array}{l}\text { To offer, sacrifice } \\
\text { Ha'i - border, edge; house }\end{array}$ \\
\hline Kao & $\begin{array}{l}\text { The continuing appearance; the continuing } \\
\text { piercing }\end{array}$ \\
\hline Auhaele & The coming and going of time/eras/cycles \\
\hline Welehu & Suspended joining/uniting of many \\
\hline Hokuula & Red star \\
\hline
\end{tabular}

Table 6. Landscape markers for Antares

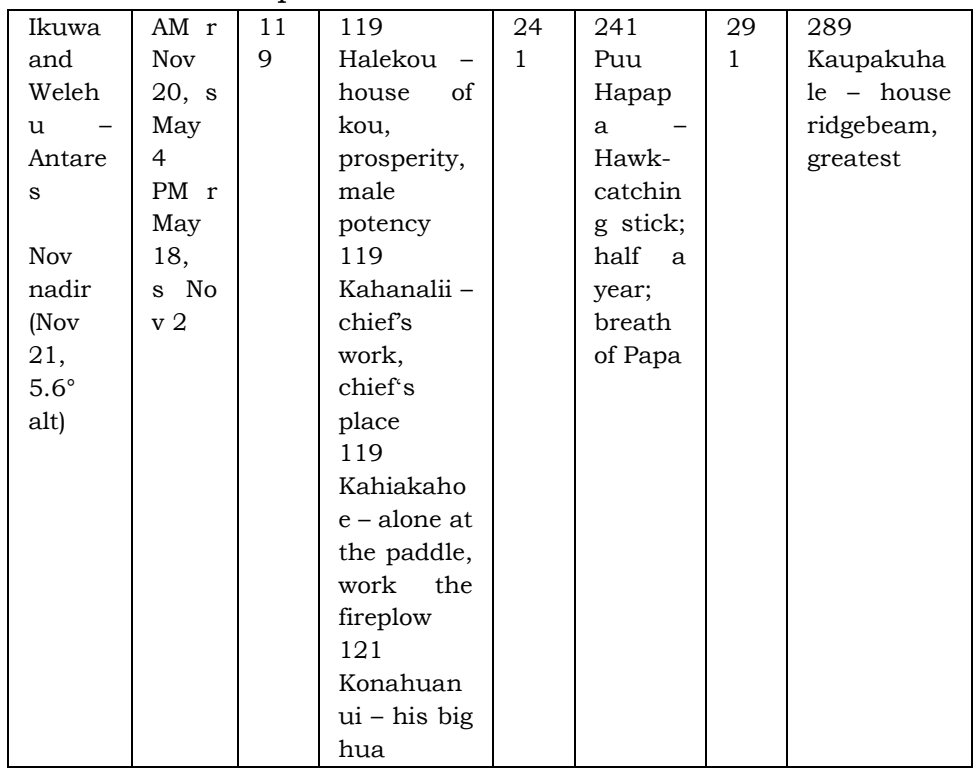

The center matters. And centering matters. The center the piko, the middle - mediates and connects separate places, times, people, and even ideas. At the center differences 
meet. The center connects and mediates between east and west, north and south, the two axes of the world. But the third axis, the axis evident in the relationship between Aldebaran and Antares, connects and mediates the opposites and includes other objects and times and places - seen as radiating lines from the axis.

One of the landscape markers for the rise of Aldebaran is Pauao. One of the meanings of Pauao is place (pā) [of] mediation, reconciliation, peacemaking ('uao). That's what third axis does. It mediates, it reconciles, it equalizes. It mediates and reconciles and equalizes in several respects. It joins the sky below and the sky above through the medium of the earth (honua, Papa). It joins east and west, the north and south, and other terrestrial axes at the piko, the center. It joins male and female through the axial union of Aldebaran (female) and Antares (male). It mediates between the pō of the womb and the $a o$ of the living the newborn child enters. It joins as equal halves the male part of the sky (east) and the female part of the sky (west) not just in the sky above the earth, but also in the sky below the earth.

The center, the piko, then, is a place of mana, a place of unity and union, a place of material and spiritual substance and essence, a place of connection and connections, a place of engagement - of insight, intuition, inspiration; of wisdom, knowledge, and understanding; engagement of awareness, knowledge and realization.

The center is a multidimensional place. The center is holistic, a hologram. But the $w \bar{a}-$ the connection of past to present to future, the connection of place to place - enhances, adds to, even alters, the experience of, and the knowledge potentially accessible at, the center. And it adds a fourth dimension - time.

Hawaiian scholar 'Umi Perkins, in his discussion of Indigenous Theory, describes its five components - (a) the concept of harmony or balance, which can be seen in the structure of Indigenous societies and could be described as dynamic equilibrium or pono; (b) the importance of place and history; (c) experience, practice, and process; (d) the holistic and 
collective nature of indigeneity; and (e) the cyclical and genealogical nature of time, represented by the spiral or koru. ${ }^{5}$

Tongan scholars Tevita Ka'ili, PhD, and Okusitino Mahina, PhD have been developing a $t \bar{a}-v \bar{a}$ (Hawaiian $k \bar{a}-w \bar{a}$ ) theory of Polynesian time and space. ${ }^{6}$ Time and space intersect.

Throughout Oceanic cultures the past is the time in front and the future is the time in back. This is reflected in understanding of island geography - the west - the direction of ancestors, beginnings, and the past - is the front of the island, and the east - what is yet to come, the future - is the back of the island.

Ka'ili and Mahina explain that $t \bar{a} / k \bar{a}$ and $v \bar{a} / w \bar{a}$ are rhythmically beaten (as on a drum) in symmetrical form in space. And that this symmetrical formation of spacetime produces harmony.

Samoan spatial design scholar, Albert Refiti, $\mathrm{PhD}$, said that "In Samoan thought, architecture is related to performing a material manifestation of 'space-towards-the-ancestors,' marked by an opening, the va. . . . This va, or co-openness, located at the centre of every gathering, every sociality, structures Samoan identity." 7

Throughout Oceania the sky is represented as a house, with main posts, a roofbeam, support posts, roof purlins, a door, and so on. The names for Aldebaran and Antares show that they are main posts of celestial structure of spacetime - of the concept of structure as a hale, a building. Aldebaran and Antares intersect with or pierce the earth as the abovebelow/up-down axis at the center that unites. They are the main front and back posts of the hale, as their Tahitian names

$5 \quad$ 'Umi Perkins, "Pono and Koru: Toward Indigenous Theory in Pacific Island Literature," Hulili, Vol. 4, No. 1, 2007, pp. 59-89, p. 59.

6 Tevita Ka'ili and Okusitina Mahina, "Working Session: Ta and Va: Moana Cultures as Specific Spatio-temporal Formation(s) in "Time and Space," Association for Social Anthropology in Oceania conference, San Diego, 2006, at http://www.soc.hawaii.edu/asao/pacific/2006sessions/13moana n.htm.

$7 \quad$ Albert Refiti, "Whiteness, Smoothing and the Origin of Samoan Architecture," Interstices, Nov. 2009, p. 10. 
show - Ana mua (post/pillar in front) and Ana muli (post/pillar in back). As Refiti said, "Light, as knowledge and understanding is not something that comes to us from outside. Rather, it appears as a divine force emanating from a centrality."8

8 ibid., p. 10. 


\section{References}

County of Hawaii, Building Code, Department of Public Works, Appendix X, Section 402, at http://www.hawaiicounty.gov/pwnew-bldg-code/.

Ka'ili, Tevita and Mahina, Okusitina, "Working Session: Ta and Va: Moana Cultures as Specific Spatio-temporal Formation(s) in "Time and Space," Association for Social Anthropology in Oceania conference, San Diego, 2006, at http://www.soc.hawaii.edu/asao/pacific/2006sessions/13moana n.htm.

Malo, David, Hawaiian Antiquities, Honolulu: Honolulu Gazette Co., 1903, p. 164 at http://www.ahamoku.org/wpcontent/uploads/2011/12/Malo-David-Hawaiian_AntiquitiesMoolelo-Hawaii-translated-by-N-B-Emerson-Honolulu-HawaiianGazette-Co-Ltd-1903.pdf.

Noyes, Martha, "From Kūkaniloko: the Celestial Rulers of Space and Time," Te Kaharoa, Vol. 10, 2017.

Perkins, 'Umi, "Pono and Koru: Toward Indigenous Theory in Pacific Island Literature," Hulili, Vol. 4, No. 1, 2007, pp. 59-89.

Refiti, Albert, "Whiteness, Smoothing and the Origin of Samoan Architecture," Interstices, Nov. 2009.

Tui Atua Tupua Tamasese Ta'isi Efi, "Tupualegase: The Eternal Riddle," Official Speeches, http://www.head-of-statesamoa.ws/pages/speech tupualegase.html. 